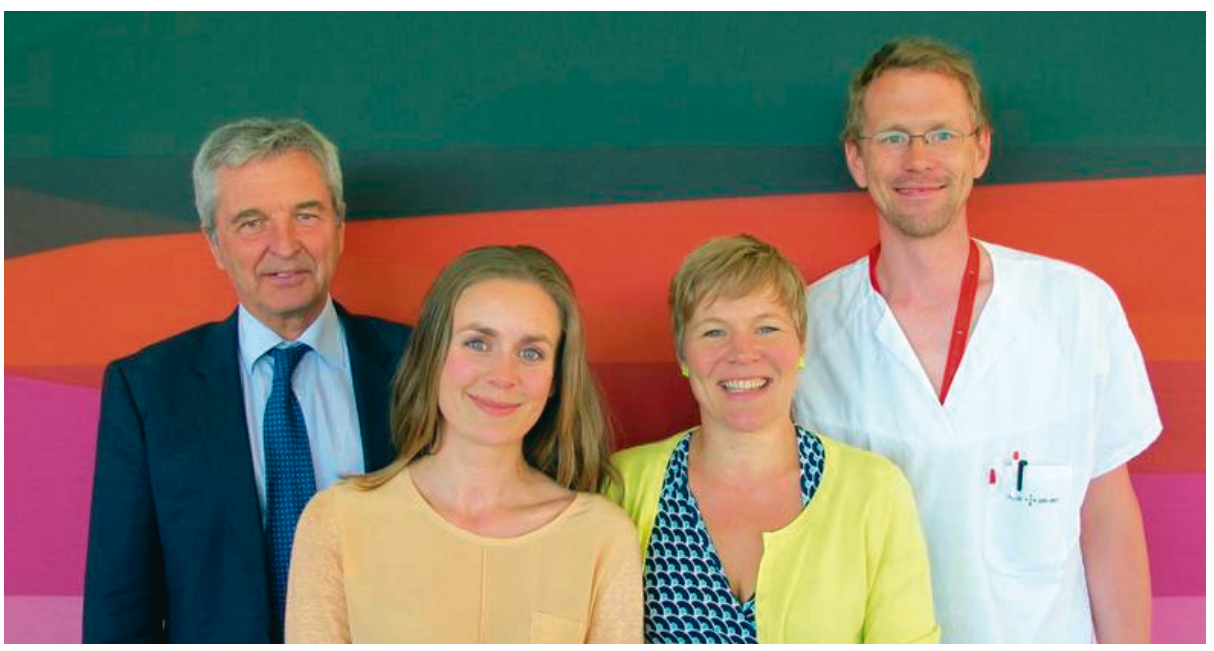

Fra venstre Tom Øresland, Nina D. Brochmann, Gunn Signe Jakobsen og Johannes Schultz. Foto: Morten Kvello
Ordforklaringer

Divertikkel: Utposning i tarmveggen, oftest sett i sigmoideum og descenderende colon.

Divertikulitt: Betennelse i en divertikkel. Har som oftest et mildt naturlig forløp.

Komplisert divertikulitt: Inkluderer abscess, perforasjon eller fisteldanning. Kirurgisk behandling kan være nødvendig, i tillegg til antibiotika.

\title{
Mindre antibiotikabruk ved divertikulitt
}

Ukomplisert divertikulitt kan trygt behandles uten antibiotika, viser norsk studie.

Akutt ukomplisert divertikulitt er en vanlig kirurgisk tilstand som ofte fører til sykehusinnleggelse. Behandlingen har tradisjonelt sett bestått av antibiotika, men en rekke studier de siste årene tyder på at antibiotika ikke er nødvendig.

I en ny studie, publisert i tidsskriftet Colorectal Disease, rapporteres erfaringer fra Akershus universitetssykehus (1). Der har man lagt om til antibiotikafri behandling av akutt ukomplisert divertikulitt. Studien er en retrospektiv gjennomgang av alle som var innlagt sykehuset med CT-verifisert ukomplisert divertikulitt i perioden 1.1. 2013-30.6. 2014, til sammen 244 pasienter. Av disse ble 177 behandlet uten antibiotika, mens 20 oppfylte forhåndsdefinerte indikasjoner for antibiotikabehandling, vanligvis annen alvorlig sykdom.

I den antibiotikafrie gruppen fikk kun én pasient en komplikasjon, i form av en fistel. Det var ingen komplikasjoner i gruppen som fikk antibiotika uten å oppfylle forhåndsdefinerte kriterier for slik behandling.

- Denne studien er en av de første som viser hvordan antibiotikafri behandling fungerer i en klinisk hverdag, sier medisinstudent Nina D. Brochmann. Hun er artikkelens førsteforfatter. - Våre erfaringer tyder på at man trygt kan avstå fra å gi antibiotika til pasienter med akutt ukomplisert divertikulitt. Nesten alle som utviklet komplikasjoner i studieperioden, var pasienter som skulle ha antibiotika uansett pga. annen alvorlig sykdom. Slike pasienter er vanligvis lette å identifisere, sier hun.

- Ved Gastrokirurgisk avdeling ved
Akershus universitetssykehus har vi valgt å skjerpe indikasjonen for antibiotika ved akutt divertikulitt. Vi håper resten av landets sykehus og allmennleger følger etter, sier Brochmann. - Divertikulitt er en svært vanlig sykdom, og ved å kutte ned på rutinemessig bruk av antibiotika håper vi å kunne bidra positivt for å hindre utvikling av antibiotikaresistens. En heldig bieffekt av en slik politikk er lavere utgifter, ettersom omleggingen ser ut til å gi færre liggedøgn og mindre intravenøs antibiotikabehandling, sier hun.

\section{Forskergruppen}

Gastrokirurgisk avdeling ved Akershus universitetssykehus har et aktivt forskningsmiljø innen kolorektalkirurgi, særlig hva gjelder divertikkelsykdom, kolorektalkreft og inflammatorisk tarmsykdom. Denne studien kom i stand etter initiativ fra Gunn Signe Jakobsen og Johannes Schultz og vil inngå i Schultz' doktoravhandling om divertikkelsykdom. Gruppen har tidligere stått bak SCANDIV-studien. Nina D. Brochmann er medisinstudent ved Universitetet i Oslo og har hatt Tom Øresland og Johannes Schultz som veiledere.

\section{Kaveh Rashidi}

Tidsskriftet

\section{Litteratur}

1. Brochmann N, Schultz JK, Jakobsen GS et al. Management of acute uncomplicated diverticulitis without antibiotics: a single centre cohort study. Colorectal Dis 2016. E-publisert 18.4.2016. 